\title{
Digital Storytelling Intervention on Prosocial Behavior Improvement among Early Childhood
}

\author{
Ifti Aisha, Dian Veronika Sakti Kaloeti \\ Fakultas Psikologi, Universitas Diponegoro, Jl. Prof. Sudarto No 13, Semarang, Indonesia \\ e-mail: dvs.kaloeti@live.undip.ac.id
}

\begin{abstract}
The prosocial behavior in childhood needs to develop because it is associated with favorable developmental outcomes in later hood. Digital storytelling is a method that assumed can help in encouraging and improving social behavior. It is combined digital media, including text, images, music and video. Digital storytelling can effectively improve prosocial behavior as opposed to the traditional storytelling approach. This study aims to examine and explore the effect of digital storytelling intervention methods on children's prosocial behavior. The research subjects were 11 preschool children ranged from 5-7 years old. This study uses a randomized experiments research design with the program is carried out consecutively in five days, consists of 1 session each day before class begins. Measurement was done by using an observation checklist which developed from five aspects (sharing, cooperating, helping, donating, honesty) of prosocial behavior. Results of Friedman test showed that there was a significant difference of prosocial behavior in each session. This finding indicates that there are differences in the value of prosocial behavior in each session after the child gets a digital storytelling program.
\end{abstract}

Keywords: digital storytelling, prosocial behavior, early childhood

\begin{abstract}
Abstrak
Perilaku prososial pada anak perlu dikembangkan karena berhubungan dengan hasil perkembangan yang positif saat dewasa. Digital storytelling adalah metode yang diasumsikan dapat membantu mendorong dan meningkatkan perilaku sosial. Metode tersebut dikombinasikan dengan media digital seperti teks, gambar, musik dan video. Digital storytelling dapat meningkatkan perilaku prososial secara efektif sebagai kebalikan dari pendekatan storytelling tradisional. Penelitian ini bertujuan menguji dan mengeksplorasi efek metode intervensi digital storytelling pada perilaku prososial anak. Subjek penelitian adalah 11 anak Taman Kanak-Kanak dengan rentang usia 5-7 tahun. Penelitian menggunakan desain randomized experiment dengan program yang dilakukan 5 hari berturut-turut, terdiri dari 1 sesi setiap hari sebelum kelas dimulai. Pengukuran menggunakan checklist observasi yang dikembangkan dari lima aspek (berbagi, bekerjasama, membantu, menyumbang, jujur) perilaku prososial. Hasil uji Friedman menunjukkan perbedaan signifikan perilaku prososial pada setiap sesi. Dapat diinterpretasikan bahwa ada perbedaan dalam nilai-nilai dari perilaku prososial dalam setiap sesi setelah anak mendapatkan program digital storytelling.
\end{abstract}

Kata Kunci: digital storytelling, perilaku prososial, masa kanak-kanak awal

\section{Introduction}

Prosocial behavior according to Dunfield (2014) is an act of helping that benefits others, where the behavior does not directly benefit people who provide help and sometimes even risking themselves. Klein (2017), in the study, showed that prosocial behavior will stimulate individuals to find positive consequences that affect their meaningful life. Further, based on the results of research conducted by Liszkowski et al. (2006) prosocial behavior begins before the child reaches the age of two. The research shows that one-year-old children have begun to entertain other people in trouble with smiling or tapping, and pointing to objects that are not affordable. Warneken and Tomasello (2007) in their study indicated that children aged one to two years begin to show their desire to help 
through action, such as taking part in searching for or getting things for others. Prosocial behavior could improve social adjustment, wellbeing (Martela \& Ryan, 2016), and academic achievement in school (Shirin, 2020). Prosocial children score higher grades from 1st grade to high school (DeVries et al., 2018). However, prosocial behavior in children could decrease and turn into antisocial behavior (Gaik et al., 2010).

This is due to several factors such as parent-child attachment, child's developmental needs, and environmental factors (Gaik et al., 2010; Riley, 2007). Based on research conducted by Kienbaum (2014), at the age of five to seven years, children have a tendency to reduce empathy and sympathy for others This study shows at this age stage the child's ability to understand the perspectives of others affects the prosocial behavior of children. Other studies shows that peer difficulties reduce prosocial behavior and increase aggressive behavior (Obsuth et al., 2015).

The results of a longitudinal study conducted by Baillargeon et al. (2011) in 2.940 infants found that lack of prosocial behavior was also seen in behavior early childhood. Some children do not want to give or help if there is no regular guidance, which is shown by the child with behaviors, such as not willing to lend his stationery to his friend, does not want to help his friend when he falls, and still exists children who do not want to share the food they have and often fight with each other (Baillargeon et al., 2011). In the development of prosocial behavior that has been carried out in schools, providing an understanding of prosocial behavior in children tends to be done orally by the teacher after the child is seen not showing prosocial behavior and inside learning situation (Jevtic, 2017). The limitations faced by teachers in accessing all children's activities and limited teacher understanding in improving prosocial behavior caused difficulties in planting prosocial behavior in children (Jevtic, 2017).

The prosocial behavior in childhood needs to develop because it is associated with favorable developmental outcomes in early childhood of social-emotional development such as more friendships, higher academic achievement, and less loneliness (Asher \& McDonald, 2009; Brett et al., 2020). Understanding ways to increase prosocial behavior is a critical step that is the foundation for individuals where this will be one of the predictors of prosocial behavior in the future (Eisenberg et al., 2007). The declination of prosocial behavior in children and adolescents shows the high symptoms of externalization in children related to the high symptoms of parental internalization (Huber et al., 2019). Donohue and Tully (2019) in their experimental research on 97 children aged 6-10 years showed that prosocial behavior in the form of apologizing, giving a gift, and replacing damaged items can help children to be adaptive to conflict situations. Furthermore, prosocial behavior in preschoolers has more to do with evaluating accepting characters (Flook et al., 2018).

Low prosocial behavior in children can influence the emergence of aggressive behavior in school (Switt \& McMaugh, 2012). Prosocial behavior can be improved through interactive learning intervention and other learning strategies (VillardónGallego et al., 2018). The give of induction and reinforcement with sharing, helping, and cooperation could improve prosocial behavior in children (Ramaswamy \& Bergin, 2009). Others stated that prosocial behavior in children could improve through religious-based intervention with giving motivation and modeling strategy (Kuswendi, 2019). On the other hand, Yulianto et al. (2019) show that cooperative learning and independence are effective ways to increase prosocial behavior. One of the essential strategies to 
cultivate prosocial behavior is through the storytelling method.

Storytelling can be interpreted as the activity of telling a story (Catala et al., 2017). Storytelling is not just recounting the stories but it can also express contents of feelings or thoughts to children verbally. It can improve children's ability to prosocial behavior because of that benefit. However, the use of storytelling requires sufficient time to prepare and apply in classroom learning. A single episode of storytelling can take at least 45 minutes (Spencer et al., 2013) The ability of teachers or students to tell the stories is also an important factor in delivering the message of the story (Woodhouse, 2011). Therefore, researchers use a more efficient method in storytelling by minimizing the shortcomings of the conventional method, namely by utilizing digital media or commonly called digital storytelling (Parsons et al., 2015). The use of digital storytelling media in this study is based on the increasing use of gadgets or tools that can be easily connected to the Internet (Sundus, 2018). Nowadays, Internetenabled devices are not only used by adults or the elderly but also by children (O'Byrne et al., 2018). The existence of attractive features offered by gadgets makes children quickly familiar with them. Therefore, researchers are interested in utilizing digital storytelling that can be accessed by children through their gadgets, as learning media that can help children to understand prosocial behavior.

Research conducted by Sari et al. (2018) revealed that one of the important elements in storytelling is that the storyteller memorizes the story, trains voices for a variety of different story characters, and uses media that is easy to use for both teachers and students. Also, the same repetitive media for stories (such as puppets) can affect students' enthusiasm in listening to stories. That was different for digital storytelling. Digital storytelling is a method of storytelling that is done by combining digital media, including text, images, recordings, narration, audio, music, and video (Dewi et al., 2018). This digital storytelling combines all these elements to convey information from a specific topic (Robin, 2016). Storytelling and digital storytelling have the same focus, namely as a storytelling method that aims to lead the audience to be able to understand the information to be conveyed. However, there are differences between them in the story presentation. Digital storytelling is supported by various digital multimedia, which combines graphics, text, recording audio, video, and music narrative to present information on certain topics through the use of technology. According to Chan and Sage (2019), the digital storytelling method can help in encouraging and improving early childhood development empathy, especially social behavior. Other studies showed that digital storytelling, which combines several strategies such as making narratives, drama, music, and visual images can support the deepening of social behavior in individuals and can ease the individuals who make the media to convey the values to be expressed to the children (Sawyer \& Willis, 2011). Also, Pieterse and Quilling (2011) also suggested that digital storytelling can be an effective method to improve emotional intelligence. Another advantage of digital storytelling according to Coventry (2008) in the presentation of the information provided, which significantly affects a person's ability to memorize and remember it in the future and the narrative presented in digital storytelling causes the audience's interest to increase, as well as help them to easily process and apply the information obtained (Coventry, 2008).

The implementation of digital storytelling can use animals, plants, and the friendship environment stories with play world educational practice method by involving students in the story in the form of general discussions, drawing activities, and free play activities (Catala et al., 2017). 
Besides, the implementation of storytelling can be interspersed with Story-Acting (STSA) due to the stories can attract children's attention (Cremin et al., 2017). Robin (2016) also stated the positive effects of digital storytelling using video editing software, music, and picture.

Some of the above studies have found that digital storytelling can improve emotional intelligence, support deepening social behavior in children, and significantly affect a person's ability to understand, memorize, and remember messages delivered significantly. Based on these explanations, researchers are encouraged to conduct interventions that aim to improve children's prosocial behavior using digital storytelling methods, especially during early childhood. Then, the hypothesis in this study, there is a significant difference in children's prosocial behavior after being given a digital storytelling intervention. Prosocial behavior is defined in terms of consequences aimed at others where the behavior is directed to promote and maintain positive benefits for the beneficiary. Also, the behavior is carried out voluntarily rather than under pressure and is not motivated by the fulfillment of professional obligations (Bierhoff, 2002). Prosocial behavior refers to a pattern of activity, voluntary actions that are intended to help or benefit another individual or group of individuals (Eisenberg \& Mussen, 1989). This definition refers to the consequences of a doer's actions rather than the motivations behind those actions. These behaviors include a broad range of activities i.e. sharing, cooperating, helping, donating, and honesty.

\section{Methods}

This study uses a randomized experiments research design, by conducting random assignments, namely the random determination of individuals into a group, the purpose of which is to determine the subjects that fall into the experimental group (Shadish et al., 2002). This ensures that every subject or participant has an equal chance of being placed in any group. Random assignment of participants helps to ensure that any differences between and within the groups are not systematic at the start of the experiment. Thus, any differences between groups that were noted at the end of the experiment can be more confidently attributed to the experimental procedures or treatment. Random assignment has several research designs, where the research design used in this study is repeated measure design. In the repeated measure design there is an experimental group formed after random assignment, and data retrieval is done repeatedly within a predetermined period (Shadish et al., 2002). We will compare the results of the posttest from each session to determine the effect of the intervention.

\section{Participants and Procedure}

Participants in this study were kindergarten students. The inclusion criteria of this study are: (a) Participants have never received prosocial behavior education in other forms other than by getting advice from teachers and parents, (b) Subjects aged 5-7 years at the start of the study; At this age, cognitive processes develop rapidly so that children can understand simple messages that are displayed in a show (Newport, in Stenberg, 2008). (c) Permission to give treatment and observation to the subjects are given both by parents and the school.

Based on inclusion criteria, as many as 33 subjects met the research criteria. Furthermore, the sampling technique in this study was carried out randomly by selecting students who had been recruited. This process produced 15 students to be involved in digital storytelling interventions. Informed consent of the willingness to participate from all students' parents has been received by the researcher so that research can be conducted. In the intervention process, as many as 4 subjects 
dropped out because they did not participate in all sessions given, so that the total remaining subjects to be analyzed amounted to 11 subjects.

The program is carried out consecutively in five days, where subjects receive 1 session each day before class begins. In each session, participants will be asked to watch digital storytelling accompanied by 4 trained observers. At the end of each session, participants were given a simple question by the observer to find out whether the subject was motivated to perform the behavior as watched. The evaluation procedure was carried out with a design of repeated measurements with posttest after each session using an observation checklist of prosocial behavior while the subject was in school.

\section{Instruments}

\section{Digital Storytelling Program}

This study combines cartoon animation with storytelling into digital storytelling using Powtoon presentation media. Digital storytelling used is a cartoon animation video where the story will be visualized with colorful cartoon animations (humanbased characters) and the sound of the storyteller that tells prosocial behavior in daily life. This program consists of 5 sessions in which there are 2 stories in each session with 4-5 minutes duration for each story. More detailed module information can be seen in the table. The development of stories in each session is based on aspects of prosocial behavior by Mussen (1989), namely sharing, cooperating, helping, donating, and honesty. Three psychologists as experts validated the content of the digital storytelling module.

The story about the aspects of prosocial behavior is packaged into a cartoon show set against the daily life of a character named Adit, the choice of background is intended so that children can easily understand the aspects of prosocial behavior carried out by the character and friends and family. The main character named Adit himself is chosen so that the child can easily remember the prosocial behaviors that the main character performs along with his friends and family so that the child can later make the main character the story as a child role model in prosocial behavior. The method was adapted based on observational learning theory according to Bandura (in Santrock, 2007) which is also called imitation or modeling, namely learning that is done when someone observes and imitates the behavior of others. In addition to showing digital storytelling, at the end of the screening, the researchers included simple questions aimed at finding out if the child was motivated to behave prosocially after seeing the digital storytelling show.

Table 1

The Module of Digital Storytelling

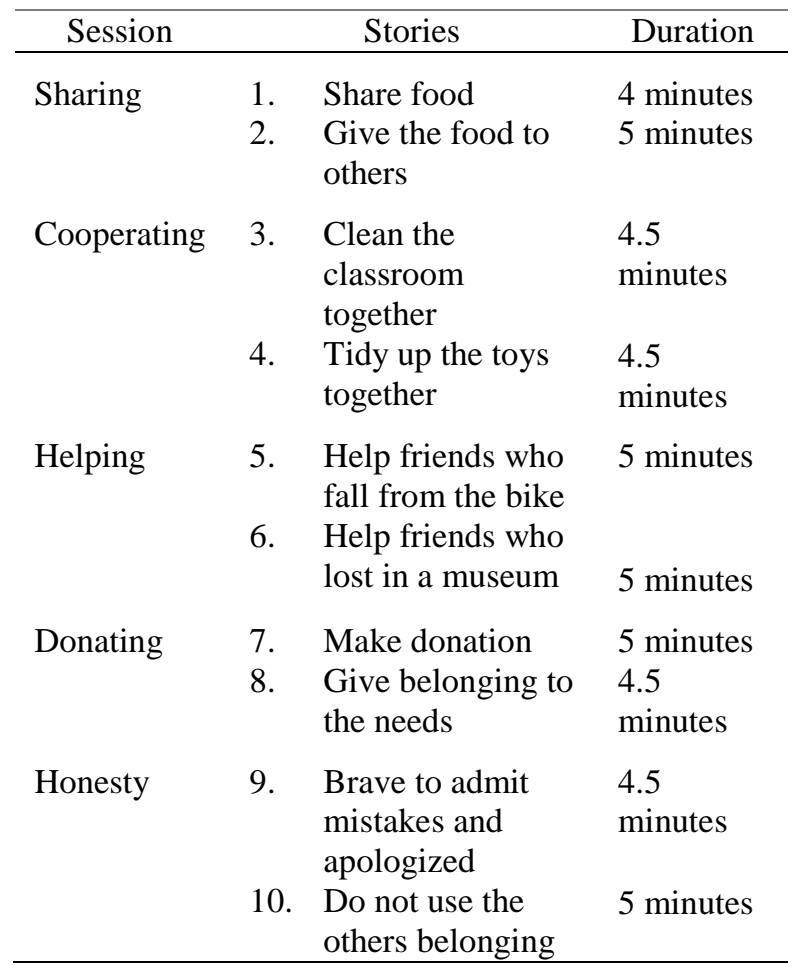

Table 2

Blueprint of Prosocial Behavior Observation Table

\begin{tabular}{lcc}
\hline \multicolumn{1}{c}{ Aspect } & $\begin{array}{c}\text { Item } \\
\text { Distribution }\end{array}$ & Percentage \\
\hline Sharing & $1,2,3$ & $33.3 \%$ \\
Cooperating & $4,5,6$ & $33.3 \%$ \\
Helping & $7,8,9$ & $33.3 \%$ \\
Donating & $10,11,12$ & $33.3 \%$ \\
Honesty & $13,14,15$ & $33.3 \%$ \\
\hline
\end{tabular}




\section{Prosocial Observation Checklist}

Measurement was done by using an observation checklist of prosocial behavior which developed from five aspects (sharing, cooperating, helping, donating, honesty) of prosocial behavior according to Mussen (1989). As presented in table 1, the aspects then implemented into 15 indicators, which were made to fit the age of participants, and expected behavioral categories. The observation checklist has gone through expert judgment and has been tested on 15 children with 4 raters through the rating scale method that produces ordinal data. The observation table is a 4 point Likert scale from 1 to 4 with reliability .965 Cronbach's alpha. Further, the reliability between rater was calculated using the Intraclass Correlation Coefficient (ICC). Reliability value between the rater got satisfactory results of .965 and was included in the excellent category, whereas for one the consistency rater is .873 , with a 95\% confidence interval quoted from (Koo \& Li, 2016), so it can conclude the observation instrument table used is reliable.

\section{Statistical Analysis}

The analysis used in this study is the Friedman Test to saw the effect of several sessions in research subjects. Also, researchers used the post hoc Wilcoxon signed-rank test which was conducted to identify groups that had significant differences. All the statistical analyses were using SPSS 20.0 considering $p<.05$ to be significant.

\section{Results and Discussion}

\section{Result}

In table 3, it can be seen that the average age of the participants was 5.2 years $(\mathrm{SD}=1.25)$ and $54.55 \%$ were female $(\mathrm{M}=1.54 ; \mathrm{SD}=.52)$. Wilcoxon SignedRank Test results in table 4 have shown a significant difference in results $(p=.008)$ between the first day and the third day, between the first day and the fourth day ( $p$
$=.008)$ between the first day and fifth day $(\mathrm{p}=.008)$.

Furthermore, the Wilcoxon Signed Rank Test results showed significant differences in results $(\mathrm{p}=.007)$ between the second day and the third day, between the second day and the fourth day $(\mathrm{p}=.008)$, significant $(\mathrm{p}=.008)$ between the second day and the fourth day $(\mathrm{p}=.008)$, between the second day $(p=.007)$. The third day showed a significant difference from the fifth day $(p=.025)$. Further, table 5 has shown the improvement of prosocial behavior skills in each given session.

Table 3

Description of Subjects

\begin{tabular}{lcc}
\hline \multirow{2}{*}{ Category } & \multicolumn{2}{c}{ Total } \\
\cline { 2 - 3 } & Frequency & $\%$ \\
\hline Gender & 5 & 45.45 \\
Male & 6 & 54.55 \\
Female & & \\
Age & 4 & 36.36 \\
5 & 4 & 36.36 \\
6 & 3 & 27.28 \\
7 &
\end{tabular}

Table 4

Wilcoxon Signed Rank Test's Result

\begin{tabular}{|c|c|c|c|c|}
\hline & Day 2 & Day 3 & Day 4 & Day 5 \\
\hline Day 1 & .065 & $.008 *$ & $.009 *$ & $.008 *$ \\
\hline Day 2 & & $.007 *$ & $.008 *$ & $.007 *$ \\
\hline Day 3 & & & .093 & $.025 *$ \\
\hline Day 4 & & & & .140 \\
\hline
\end{tabular}

Table 5

Mean Rank of Each Session

\begin{tabular}{lcccc}
\hline & & \multicolumn{3}{c}{$\begin{array}{c}\text { 95\% Confidence } \\
\text { Interval }\end{array}$} \\
\cline { 2 - 5 } & $\begin{array}{c}\text { Mean } \\
\text { Rank }\end{array}$ & SE & $\begin{array}{c}\text { Lower } \\
\text { Bound }\end{array}$ & $\begin{array}{c}\text { Upper } \\
\text { Bound }\end{array}$ \\
\hline Session 1 & 1.59 & 2.51 & 42.84 & 54.06 \\
Session 2 & 2.18 & 1.62 & 47.83 & 55.07 \\
Session 3 & 3.32 & 1.35 & 51.61 & 57.65 \\
Session 4 & 3.68 & 1.00 & 54.93 & 59.42 \\
Session 5 & 4.23 & .93 & 56.45 & 60.63 \\
\hline
\end{tabular}




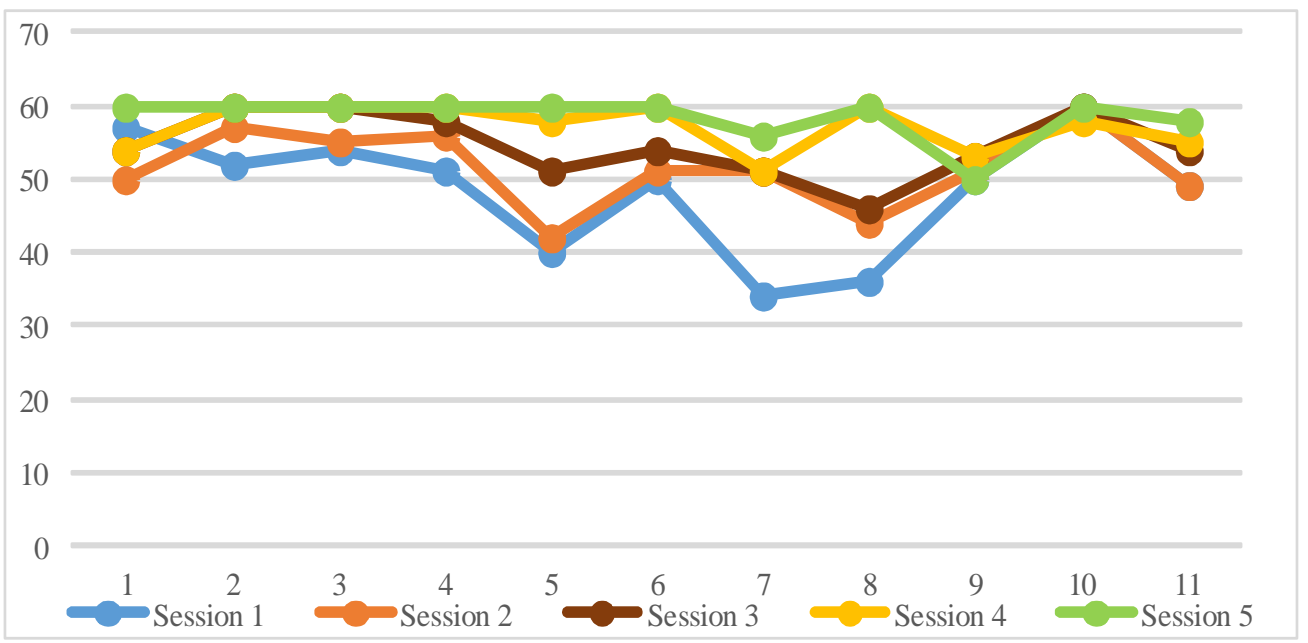

Figure 1. Prosocial behavior score in each session of intervention program

Figure 1 has shown the prosocial behavior score in each session. It can be shown that children who experienced an increase in prosocial behavior from the first session to the fifth were more in number compared to children who experienced a decline in one session and children who tend to be stagnant. As many as two children experienced a decrease in scores at the second session and one child experienced a decrease in scores at the fifth session and one child has a score that tends to be the same from all the sessions.

\section{Discussion}

The results of this study are in line with previous studies conducted by Paiva (2005) and Hibbin (2016) that the application of the method of storytelling with audio-visual media (digital storytelling) is effective in improving children's empathy skills. Besides, telling stories with audiovisual media can also train absorption or the ability to catch the attention of young children, develop children's imagination, and create exciting situations. This result is also in line with the research conducted by Garcia and Rossiter (in Robin, 2016) that the use of learning with digital storytelling in students is to increase empathy, perspective-taking, self-understanding, and community building.

Among observations through five sessions that have been given, the increased prosocial behavior between the first sessions (sharing) with the second session (cooperating) showed no significant results. Likewise between the fourth session (donating) and the fifth session (honesty). It is assumed caused by the need for time in the processing of new behaviors. When learning new behaviors, children are given a new stimulus that may not be by their present knowledge. This change will make children make the process of adaptation and assimilation where it takes time (Di Paolo et al., 2014). The intervention program that was followed by the subject, in the initial form of cognitive schemes that needed time to be transformed into new behaviors of learning outcomes.

Another factor that can be the reason for the absence of significant differences between five meetings (first day until the fifth day) can also be caused by age differences. This study was conducted on 11 subjects who had ages between five to seven years. Observers also noted that some of the participants looked shy to answer questions, but looked more active and confident when involved in playing activities with their friends. Based on research conducted by Al-Mousawi and 
Alsumait (2012), the age factor of different children can lead to differences in results that are not significant in giving digital storytelling to children is. The study compared 4 years old children with children aged 5 to 6 years old. The results found that younger children seemed freer to express themselves and their thoughts, while children aged five or six years who were more aware of themselves, so the children at the age of five to six begin to feel embarrassed if they have to express themselves and their thoughts, and make them look less confident.

Another study conducted by Kienbaum (2014) compared the sympathy of children reveals that the older the child is, their sympathy for others increases, and their empathy for others decreases. This is because the child begins to see whether he wants to help the other person or The observers recorded children's desire to help their older friends, but the children did not want to help at all if one of the friends whom they thought was naughty needed help. Thus, the study of Kienbaum (2014) provides the reason that the selection of children to help or have a sense of empathy and sympathy for others is influenced by the child's age. In addition to the existence of maximum value and age factors, other factors that can cause differences in insignificant prosocial behavior are influences in the child's social environment, this is because children who are in a social environment that implements prosocial behavior will be easier to understand the moral values given by linking these values with their social environment (Kraus \& Callaghan, 2016).

Furthermore, another factor that could be the cause of the non-significant changes in prosocial behavior in several meetings, is the total duration for the children to learn prosocial behavior is too short. so the short duration of the intervention can be a limitation in this study and the results cannot be generalized as a result of the population under study for a long time. based on research conducted by Bratitsis and Ziannas (2015) the short duration of research can be a limitation in research, because the results cannot be generalized as a result of the population studied for a long period.

Social learning theory states that most human behavior is studied, constructed, and shaped by environmental events, especially rewards, punishments, and modeling (Lam, 2012). Modeling is a social process in which patterns of behavior are acquired and transmitted. It involves learning observation, identification, and imitation (Bandura, 1986). From a social learning perspective, learning about prosocial behavior is interpreted as a consequence of reinforcement or modeling captured by children through digital storytelling.

\section{Conclusion}

Although the present study provided the benefits of digital storytelling as a medium for preschool children to learn prosocial behavior, further provision of group control, baseline measurements, and intervention duration are the essential areas for future studies. Also, this study did not specifically categorize participants based on age, gender, children's backgrounds, such as the children's social-economic status, parental income, parents' parenting behavior, and age that might affect the children's prosocial behavior.

\section{References}

Al-mousawi, Z., \& Alsumait, A. (2012). A digital storytelling tool for Arab children. 26-35. https://doi.org/10.1145/2428736.24287 46

Asher, S. R., \& McDonald, K. L. (2009). The behavioral basis of acceptance, rejection, and perceived popularity. In K. H. Rubin, W. M. Bukowski, \& B. Laursen (Eds.), Handbook of peer interactions, relationships, and groups (pp. 232-248). The Guilford Press. 
Baillargeon, R. H., Morisset, A., Keenan, K., Normand, C. L., Jeyaganth, S., Boivin, M., \& Tremblay, R. E. (2011). The development of prosocial behaviors in young children: A prospective population-based cohort study. The Journal of Genetic Psychology, 172(3), 221-251. https://doi.org/10.1080/00221325.2010 $.53 \mathrm{e} 719$

Bandura, A. (1986). Social foundations of thought and action: A social cognitive theory. Prentice-Hall.

Bierhoff, H. W. (2002) Prosocial Behaviour. Psychology Press.

Bratitsis, T., \& Ziannas, P. (2015). From early childhood to special education: Interactive digital storytelling as a coaching approach for fostering social empathy. Procedia Computer Science, 67 , 231-

240. https://doi.org/10.1016/j.procs.20 15.09.267

Brett, B. E., Stern, J. A., Gross, J. T., \& Cassidy, J. (2020). Maternal depressive symptoms and preschoolers' helping, sharing, and comforting: The moderating role of child attachment. Journal of Clinical Child \& Adolescent Psychology, 49. https://doi.org/10.1080/15374416.2020 .1738235

Catala, A., Theune, M., Gijlers, H., \& Heylen, D. (2017). Storytelling as a creative activity in the classroom. Proceedings of the 2017 ACM SIGCHI Conference on Creativity and Cognition-C\&C, 17. https://doi.org/10.1145/3059454.30788 57

Cremin, T., Flewitt, R., Swann, J., Faulkner, D., \& Kucirkova, N. (2017). Storytelling and story-acting: Co-construction in action. Journal of Early Childhood Research, 16(1), 317.

https://doi.org/10.1177/1476718X1775 0205
Chan, C., \& Sage, M. (2019). A narrative review of digital storytelling for social work practice. Journal of Social Work Practice.

https://doi.org/10.1080/02650533.2019 .169280

Coventry, M. (2008). Engaging gender: Student application of theory through digital storytelling. Arts and Humanities in Higher Education, 7, 205-219.

https://doi.org/10.1177/147402220808 8649

DeVries, J. M., Rathmann, K., \& Gebhardt, M. (2018). How does social behavior relate to both grades and achievement scores? Frontiers in Psychology, 9. https://doi.org/10.3389/fpsyg.2018.0 0857

Dewi, N. R., Kannapiran, S., \& Wibowo, S. W. A. (2018). Development of digital storytelling-based science teaching materials to improve students' metacognitive ability. Indonesian Journal of Science Education, 7(1). https://doi.org/10.15294/jpii.v7i1.1271 8

Di Paolo, E. A., Barandiaran, X. E., Beaton, M., \& Buhrmann, T. (2014). Learning to perceive in the sensorimotor approach: Piaget's theory of equilibration interpreted dynamically. Frontiers in Human Neuroscience, $\quad 8(1), \quad$ 551-567. https://doi.org/10.3389/fnhum.2014.00 551

Dunfield, K. A. (2014). A construct divided: Prosocial behavior as helping, sharing, and comforting subtypes. Frontiers in Psychology, 2(5). https://doi.org/10.3389/fpsyg.2014.009 58

Donohue, M. R., \& Tully, E. C. (2019). Reparative prosocial behaviors alleviate children's guilt. Developmental Psychology, 55(10), 2102-2113. https://doi.org/10.1037/dev0000788 
Eisenberg, N. Fabes, R. A., \& Spinrad, T. (2007) Prosocial development. John Wiley and Sons.

Eisenberg, N., \& Mussen, P. H. (1989). The roots of prosocial behavior in children. Cambridge University Press.

Flook, L., Zahn-waxler, C. Z., \& Davidson, J. (2018). Developmental differences in prosocial behavior between preschool and late elementary school. Front Psychol, 10, 876. https://doi.org/10.3389/fpsyg.2019.008 76

Gaik, L. P., Abdullah, M. C., Elias, H., \& Uli, J. (2010). Development of antisocial behaviour. Procedia-Social and Behavioral Sciences, 7, 383388. https://doi.org/10.1016/j.sbspro.20 10.10.052

Huber, L., Plötner, M., \& Schmitz, J. (2018). Social competence and psychopathology in early childhood: A systematic review. Eur Child Adolesc Psychiatry, 28(4), 443-459. https://doi.org/10.1007/s00787-0181152-x

Hibbin, R. (2016). The psychosocial benefits of oral storytelling in school: Developing identity and empathy through narrative. Pastoral Care in Education, 34(4), 218231. https://doi.org/10.1080/02643944. 2016.1225315

Jevtic, B. (2017). The attitude of teachers towards prosocial behavior and academic achievement in Serbia. Problems of Education in The 21st Century, 75(1), 34-54.

Kienbaum, J. (2014). The development of sympathy from 5 to 7 years: Increase, decline, or stability? A longitudinal study. Frontiers in Psychology, 5, 110.

https://doi.org/10.3389/fpsyg.2014.004 68

Klein, N. (2017). Prosocial behavior increases perceptions of meaning in life. The Journal of Positive Psychology, https://doi.org/10.1080/17439760.2016 .1209541

Kraus, M. W., \& Callaghan, B. (2016). Social class and prosocial behavior. Social Psychological and Personality Science, 7(8), 769-777. https://doi.org/10.1016/j.copsyc.2017.0 6.003

Kuswendi, U. (2019). Teacher strategy in development prosocial behavior of students in elementary school. Journal of Elementary Education, 3(1). https://doi.org/10.22460/pej.v3i1.1231

Koo, T. K., \& Li, M. Y. (2016). A guideline of selecting and reporting intraclass correlation coefficients for reliability research. Journal of Chiropractic Medicine, 15(2). https://doi.org/10.1016/j.jcm.2016.02.0 12

Lam, C. M. (2012). Prosocial involvement as a positive youth development construct: A conceptual review. Scientific World Journal. https://doi.org/10.1100/2012/769158

Liszkowski, U., Carpenter, M., Striano, T., \& Tomasello, M. (2006). 12-and 18month-olds point to provide information for others. Journal of Cognition and Development, 7(2), 173187.

https://doi.org/10.1207/s15327647jcd0 702_2

Martela, F., \& Ryan, R. M. (2016). Prosocial behavior increases well-being and vitality even without contact with the beneficiary: Causal and behavioral evidence. Motivation and Emotion, 40(3), 351357. https://doi.org/10.1007/s11031016-9552-z

Mussen, P. H., Conger, J. J., \& Kagan, J. (1989). Child development and personality $\left(5^{\text {th }}\right.$ ed.). Harper and Row Publishers.

Obsuth, I., Eisner, M. P., Malti, T., \& Ribeaud, D. (2015). The developmental relation between aggressive behaviour and prosocial 
behaviour: A 5-year longitudinal study.

$B M C$ Psychology,

3(1). https://doi.org/10.1186/s40359-

015-0073-4

O'Byrne, W. I., Houser, K., Stone, R., \& White, M. (2018). Corrigendum: Digital storytelling in early childhood: Student illustrations shaping social interactions. Frontiers in Psychology, 9.

https://doi.org/10.3389/fpsyg.2018.027 49

Paiva, A., Dias, J., Sobral, D., Aylett, R., Woods, S., Hall, L., \& Zoll, C. (2005). Learning by feeling: Evoking empathy with synthetic characters. Applied Artificial Intelligence: An International Journal, 19(3-4): 235-266. https://doi.org/10.1080/088395105909 10165

Parsons, S., Guldberg, K., PorayskaPomsta, K., \& Lee, R. (2015). Digital stories as a method for evidence-based practice and knowledge co-creation in technology-enhanced learning for children with autism. International Journal of Research \& Method in Education, 38(3), 247-271. https://doi.org/10.1080/1743727x.2015 .1019852

Pieterse, G., \& Quilling, R. (2011).The impact of digital story-telling on trait emotional intelligence (EI) amongst adolescents in South Africa-A case study. Social and Behavioral Sciences, 28 ,

156-163. https://doi.org/10.1016/j.sbspro.2011.1 1.031

Ramaswamy, V., \& Bergin, C. (2009). Do reinforcement and induction increase prosocial behavior? Results of a teacher-based intervention in preschools. Journal of Research in Childhood Education, 23(4), 527538. https://doi.org/10.1080/02568540 909594679

Riley, D. (2007). Anti-social behaviour: Children, schools and parents. Education and the Law, 19(3-4), 221-
236. https://doi.org/10.1080/09539960 701762870

Robins, B. (2016). The power of digital storytelling to support teaching and learning. Digital Education, 30. https://doi.org/10.1344/der.2016.30.1729

Santrock. (2007). Perkembangan anak jilid 2 (terjemahan). Erlangga.

Sari, I. T. M., Toha, H., \& Nurani, Y. (2018). Improving early childhood prosocial behavior through activity storytelling with puppets. Jurnal Pendidikan Anak Usia Dini, 2(2), 155161.

https://doi.org/10.31004/obsesi.v2i2.75

Sawyer, C. B., \& Willis, J. M. (2011) Introducing digital storytelling to influence the behavior of children and adolescents. Journal of Creativity in Mental Health, 6(4), 274-283. https://doi.org/10.1080/15401383.2011 .630308

Shadish, Cook, \& Campbell. (2002). Experimental and quasi experimental design for generalized causal inference. Houghton Mifflin Company.

Shirin, A. (2020). Determining the relationship between academic achievement and prosocial behavior of secondary school students in Dhaka City. International Journal of Research and Reveiews in Education, 6-15.

https://doi.org/10.33500/ijrre.2020.6.0 02

Spencer, T. D., Kajian, M., Petersen, D. B., \& Bilyk, N. (2013). Effects of an individualized narrative intervention on children's storytelling and comprehension skills. Journal of Early Intervention, 35(3), 243269. https://doi.org/10.1177/10538151 14540002

Stenberg, R. J. (2008). Psikologi kognitif. Pustaka Pelajar.

Sundus, M. (2018). The impact of using gadgets on children. Journal of Depression and Anxiety, 7(1), 1-3. 
https://doi.org/10.4172/2167-

1044.1000296

Switt, C., \& McMaugh, A. (2012).

Relational agression and prosocial behavior in Australian preschool children. Australian Journal of Early Childhood, 37(3). https://doi.org/10.1177/183693911203 700305

Villardón-Gallego, L., García-Carrión, R., Yáñez-Marquina, L., \& Estévez, A. (2018). Impact of the interactive learning environments in children's prosocial behavior. Sustainability, 10(7), 21-38. https://doi.org/10.3390/su10072138

Woodhouse, H. (2011). Storytelling in university education: Emotion, teachable moments, and the value of life. The Journal of Educational Thought, 45(3), 211-238. https://doi.org/10.11575/jet.v45i3.5221 8

Yulianto, D., Yufiarti., \& Akbar, M. (2019). A study of cooperative learning and independence: Impact on children's prosocial behavior. International Journal of Education, 12(1), 49-55. https://doi.org/10.17509/ije.v12i1.1752 2 